\title{
DETERMINATION OF THE ELGACIN EFFECT ON THE CELLULAR COMPONENT OF THE IMMUNE SYSTEM IN AGED RATS
}

\author{
O.Yu.Koshova \\ National University of Pharmacy \\ Key words: ageing; cell-mediated immunity; geroprotectors; ellagotanins, elgacin
}

\begin{abstract}
The study of the effect of a new original drug with antioxidant properties - "Elgacin" tablets on cellular component of the immune system of old mice in conditions of the delayed hypersensitivity reaction has been conducted. It has been found that decrease in reactivity of the cell-mediated response takes place in ageing. Introduction of "Elgacin" tablets to old mice contributed to restoration of the immune response on introduction of the antigen up to the physiological level of young animals. It testify in favour of its potential geroprotective properties regarding age-dependent changes of the immunity. The data obtained substantiate the further research of "Elgacin" tablets.
\end{abstract}

Gradual immunity suppression takes place during the ageing process. It results in increase of frequency and severity of infectious diseases, cancer and autoimmune disorders. First of all, during ageing the functionality of the T-system of the immunity changes, in particular the ability to distinguish the allotypic antigen by macrophagocytes and lymphocytes. The activity of helper T-cells (not only TH1, but also TH2) is suppressed, the suppressor function of the immune system is disturbed, the activity of metabolic processes in phagocytes and other cells that are responsible for nonspecific anti-infectious reactivity is decreased [6].

Thus, typical diseases of elderly age are associated with decrease of the immune reactivity as a result of profound changes in the population structure of T-cells and their functions. It is also the result of the activity of cells that participate in nonspecific cell-mediated and antibody-mediated reactions in ageing.

The abovementioned determines the relevance of search for a geroprotective agent with affinity to the immune system. The Central Research Laboratory of the National University of Pharmacy conducts the study of a new original antioxidant drug "Elgacin" as a geroprotector. The active substances of "Elgacin" are elagotanins isolated from collective fruit of sticky adler and grey adler (Alnus glutinosa L., Alnus cinerea L.). In experiments on rats of different age it has been found that administration of "Elgacin" prevents development of age dependent disorders of the liver, heart, carbohydrate and lipid metabolism [2].

The aim of this work was to determine the effect of "Elgacin" tablets on the cellular component of the immune system of aged rats.

\section{Materials and Methods}

The experiments were conducted on 100 outbred male mice of the young fertile age (6 months with the body mass of 18.0-20.0 g) and mice of the old age (20 months, $30-35 \mathrm{~g}$ ). During the experiment animals were kept in standard conditions at $18-24^{\circ} \mathrm{C}, 50-60 \%$ of humidity, "day-night" natural light regime, a balanced diet with free access to water. All procedures with animals were performed according to the principles of the "European convention for the protection of vertebrate animals used for experimental and other scientific purposes" (Strasbourg, 1986), according to the GLP standards [1]. The condition of the cell mediated immunity was assessed by the delayed hypersensitivity reaction using the method of K.P.Kitamura with determination of the reaction index (RI) [5]. Mice were immunized by thymusdependent antigen - sheep erythrocytes (SE). The animals were divided into the following groups (10 animal in each group): group 1-2 - nonimmune (intact) control of the fertile age and old age; group 3-4 - immunized control (SE) of the fertile and old age; group 5-6animals of the old age that received the drug under research in the dose of 1.4 and $14 \mathrm{mg} / \mathrm{kg}$ before and during the whole period of immunization by SE. Doses of "Elgacin" tablets for mice were re-calculated from a conditionally therapeutic dose for rats previously determined taking into account the dose conversion factor by body area [3]. The drug studied was introduced to mice intragastrically once a day within 3 days prior and during the whole immunization period.

The experimental data obtained were processed using methods of analysis of variance with the help of the "Statistica 6.0" statistic programme.

\section{Results and Discussion}

As it was mentioned above, the progressive suppression of all components of the immune system occurs while ageing. The highest immune response is registered during the period of puberty, but in elderly people it composes only $1-2 \%$ from this level. Progressive suppression of the thymus-dependent immune component is associated with aged-related involution of the thymus. This is expressed in its mass reduction, weakening of its function and synthesis of regulatory factors. The humoral compo- 
Reaction index of delayed hypersensetivity in mice of different age

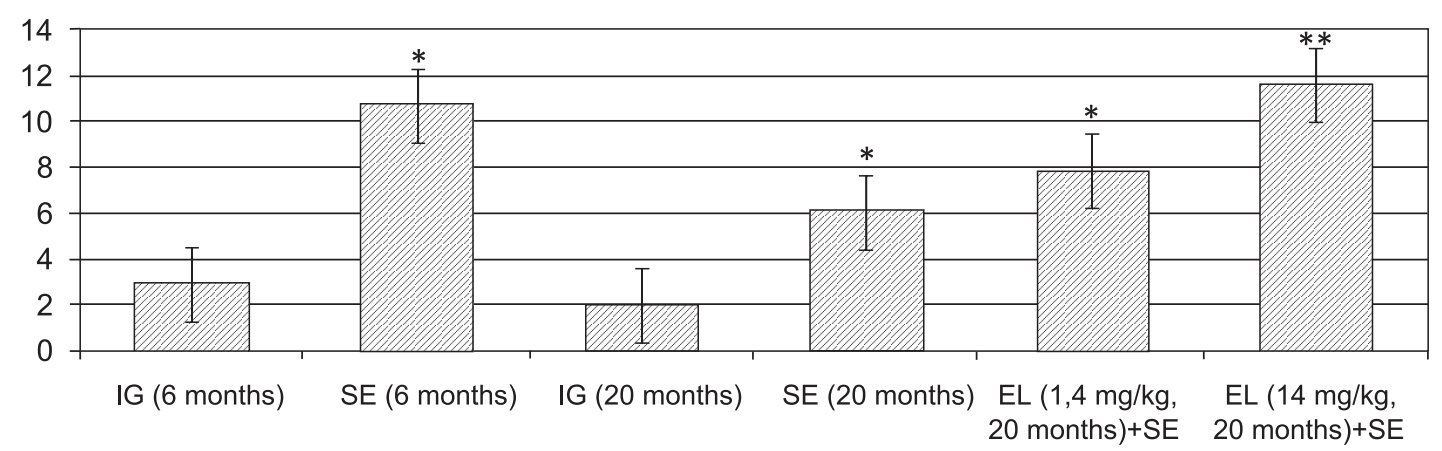

Fig. The effect of "Elgacin" tablets in the doses of 1.4 and $14 \mathrm{mg} / \mathrm{kg}$ on the cell-mediated immune response of mice with the normal immune status $(n=10)$.

Notes: Intact group (6 months); Intact group (20 months) - the intact control of fertile and old age, respectively; SE (6 months); SE (20 months) - the immunized control of the fertile and old age, respectively. EL $(1,4 ; 14 \mathrm{mg} / \mathrm{kg}, 20$ months)+SE - mice aged 20 months that received "Elgacin" in the doses of 1.4 and $14 \mathrm{mg} / \mathrm{kg}$ on the background of immunization.

* - statistically significant differences compared to the intact group of the fertile age, $p<0.05$; ** - statistically significant differences compared to the immunized SE group of the old age, $p<0.05$.

nent of the immunity also undergoes negative changes in ageing: decrease in the level of normal antibodies, including isohaemoglutinins, is observed [4].

According to the data obtained there was the normal immune response to introduction of sheep erythrocytes in young mice (Fig.). In old mice the decrease in the reaction index in 1.6 times compared to immunized animals of the fertile age was registered. It indicates a significant decrease in the immune response on introduction of the thymus-dependent antigen (Fig.).

When introducing "Elgacin" tablets in the dose of $1.4 \mathrm{mg} / \mathrm{kg}$ the tendency to increase the reaction index of delayed hypersensitivity was observed (Fig.). The increase in the dose of the tablets led to restoration of the immune response in old mice up to the normal level. The RI of delayed hypersensitivity in mice that received the drug studied was almost twice higher compared to old animals. And it had no difference from the values of the RI in the group of immunized animals of the fertile age (Fig.). The given differences between groups were statistically significant.

A positive effect of "Elgacin" tablets on the immune system of aged rats apparently can be explained by stimulating impact of elagotanins on inflammation mediators of the cellular component of the immunity determined in the experiments in vivo and in vitro, in particular interleukin 1 and tumour necrosis factor alpha $((\mathrm{TNF}-\alpha)[7,8]$.

CONCLUSIONS

1. The results of the study conducted confirm the literature data concerning decrease of the immune reactivity in ageing.

2 . The data obtained demonstrate the immunomodulatory properties of "Elgacin" tablets towards the cellular component of the immunity in old mice. These data substantiate the further research in this field.

\section{REFERENCES}

1. Директива Совета ЕС о сближении законов, постановлений и администрирование положений государств ЕС по вопросам защиты животных, используемых для экспериментальных и других научныхх иелей (86/609/EЕС) / В кн.: Надлежсащая производственная практика лекарственных средств; Под ред. Н.А.Ляпунова, В.А.Загория, В.П.Георгиевского, Е.П.Безуглой. - К.: Морион, 1999. - С. 508-545.

2. Яковлєва Л.В., Карбушева І.В., Лар'яновська Ю.Б. // Фармаком. - 2004. - №3. - С. 36-41.

3. Freireich E.J., Gehan E.A., Ral D.P. et al. // Cancer Chemother. Rep. - 1966.- Vol. 50, №4. - P. 219-244.

4. Hajo Haase. The immune system and the impact of zinc during aging / Hajo Haase, Lothar Rink [Electronic resource] // Immunity \& Ageing. - 2009. - №6 (9). - Access mode: http://www.immunityageing.com/content/6/1/9.

5. Kitamura K.A. // J. Immunol. Methods. - 1980. - Vol. 39. - P. 277-283.

6. Meyer K.C. // Proc. Am. Thorac. Soc. - 2005. - №2. - P. 433-439.

7. Miyamoto K., Murayama T., Nomura M. et al. // Anticancer Res. - 1993. - Vol. 13. - P. 37-42.

8. Yoshida T., Amakura Y., Yoshimura M. // Int. J. Mol. Sci. - 2010. - Vol. 6; №11 (1). - P. 79-106. 


\section{ВИЗНАЧЕННЯ ВПЛИВУ ЕЛГАЦИНУ НА КЛІТИННУ ЛАНКУ ІМУНІТЕТУ СТАРИХ МИШЕЙ О.Ю.Кошова}

Ключові слова: старіння; клітинний імунітет; геропротектори; елаготаніни; елгацин Проведено вивчення впливу нового оригінального засобу з антиоксидантними властивостями таблеток «Елгацин» на клітинну ланку імунітету старих мишей за умов реакції гіперчутливості повільного типу. Встановлено, що при старінні спостерігається зниження реактивності клітинного імунітету. Введення таблеток "Елгацин» старим мишам сприяло відновленню імунної відповіді на введення антигену до фрізіологічного рівня молодих тварин, що свідчить про його потенційні геропротекторні властивості щодо вікових змін імунітету. Отримані дані обгрунтовують перспективність подальщих досліджень елгацину у цьому напрямку.

\section{ОПРЕДЕЛЕНИЕ ВЛИЯНИЯ ЭЛГАЦИНА НА КЛЕТОЧНОЕ ЗВЕНО ИММУНИТЕТА СТАРЫХ МЫШЕЙ \\ Е.Ю.Кошевая}

Ключевые слова: старение; клеточный иммунитет; геропротекторы; эллаготанины; элгацин

Проведено изучение влияния нового оригинального препарата с антиоксидантными свойствами таблеток «Элгацин» на клеточное звено иммунитета старых мышей в условиях реакции гиперчувствительности замедленного типа. Установлено, что при старении наблюдается снижение реактивности клеточного иммунитета. Введение таблеток «Элгацин» старым мышам способствовало восстановлению иммунного ответа на введение антигена до фризиологического уровня молодых животных, что свидетельствует о его потенциальных геропротекторных свойствах относительно возрастных изменений иммунитета. Полученные данные обосновывают перспективность дальнейших исследований элгацина в этом направлении. 